\title{
ENVIRONMENTAL LEARNING APPROACHES IN IMPROVING LEARNING OUTCOMES IN ACID-BASE SUBJECT
}

\author{
Rachmat Sahputra ${ }^{1)}$, Dwi Widiarti' ${ }^{2}$, Rahmat Rasmawan ${ }^{3)}$ \\ ${ }^{1,2}$ and $^{3)}$ Chemistry education of FKIP Untan \\ E-mail:rahmat_ui@yahoo.com
}

\begin{abstract}
Learning in the understanding of acid-base chemistry in schools needs to be improved so research to determine differences in learning outcomes between students taught using environmental approaches and methods lectures in class XI SMA on acid-base subject needs to be done. In this study, using a quasi-experimental method using a data collection tool achievement test essay form. The test statistic results of the post-test learning has been obtained Asymp value. Sig (2-tailed) 0,026 that showed the differences between students' learning outcomes with a control experimental class with effect size of 0.63 or much influence difference with the percentage $23.57 \%$ which indicated that the learning environment approach can improve learning outcomes of high school students.
\end{abstract}

Keywords: Environment approach, motivation, learning outcomes

\section{INTRODUCTION}

Learning activities conducted by the students is a process attempts person to obtain a new change in behavior as a whole, as a result of his own experience in interaction with the environment [1].

The chemistry is a part of natural science that is used to understand natural events through systematic methods. The chemistry that learned not only to find chemicals that directly benefit the welfare of mankind, but the chemistry can be used to understand natural events that are found in everyday life, knowing the nature of the subject and changes its form, applying the scientific method, and can develop ability to propose ideas. [2] stated that chemistry is a part of natural science that studies the composition and structure of chemical substances, as well as its relationship both with the nature of the substance.

According to Susanto [3], there are three problems in science learning. First, science education is oriented on product knowledge only and less oriented to the process of science. Second, science teaching devoted only based on the knowledge without practice or laboratory work. Third, the teaching of science focused on the teacher as the students answered questions in accordance with the taught by a teacher or written textbook. Students should explore their own problems and find answers to the problem through a practicum or trial. Thus it takes innovation in the learning process to make it more meaningful such as by using the environmental approach. According [4], environmental approach is an approach to learning that seeks to increase student engagement through the utilization of the environment as a learning resource. In line with the statement of [5] which states that environmental approaches to learning can encourage the creation of learning fun and to improve students' motivation in learning. According to [6] with the motivation to make a student able to learn more extra to achieve the learning outcomes as desired.

Based on the observation of the learning process at colloid chemical subject in class XI SMAN 1 Sungai Raya on January 13, 2015, learning process is still centered on the teacher. This causes students to feel bored and not motivated to follow the lesson. The low student motivation adversely affects the student learning outcomes. This is evident from the percentage of completeness learning outcomes of students grade XI in restating the end of the first semester is still low with an average percentage of $15.42 \%$. While the percentage of completeness student learning outcomes in acid-base subject of the school year 2013/2014 amounted to only $38.1 \%$.

Results of interviews with five students of class XI Science shows that students are less able to 
understand the subject presented for the teacher to explain too fast, rarely use the media, not doing practical and motivating learning to students and often give homework but not discussed as a whole.

Based on these problems researchers interested in conducting research to determine the effect of learning by using environmental approach to motivation and learning outcomes of students of class XI in acid-base subject.

\section{METHOD}

This study aims to determine the effect of learning with environmental approach to motivation and learning outcomes of students of class XI IPA at SMAN 1 Sungai Raya on acid-base subject. Forms of research is experimentation with form a quasi-experimental design or quasi-experimental design.

The population in this study were all students of class XI IPA 1, IPA 2 IPA 3 IPA 4 and IPA 5 in SMA Negeri 1 Sungai Raya, while the subjects were students of class XI IPA 1 ( 30 person) and IPA 4 (23 person). In this research, sample selection was done by purposive sampling. Researchers selected a sample based on learning outcomes for a repeat end of the semester and the results of discussions with teachers of chemistry lesson. Samples were taken two classes based on the average value of replications end of the semester is almost the same. Selection of the control and experimental classes performed by lottery.

Data collection techniques used is a measurement technique with a data collector in the form of learning and motivation questionnaire about the pretest and post-test. The research instruments validated by one lecturer of chemical education in FKIP Untan and the teachers of chemistry subject at SMA Negeri 1 Sungai Raya. Based on trial results obtained information about the level of reliability that the matter is prepared is low with a coefficient of 0.25 . Student motivation questionnaire using Likert scale. The response of the statement on the student questionnaire responses are divided into four categories, strongly agree (SS), agree (S), disagree (TS), and strongly disagree (STS). While the test to determine differences in learning outcomes between control and experimental classes used SPSS 22. The detailed procedure of this study consisted of three phases: the preparation phase, the implementation phase, and phase analysis.

The preparation phase: at this stage of the pre-research, prepare research instruments (tests of learning outcomes, motivation questionnaire, lesson plan (RPP) with environmental approach, lesson plan (RPP) with lectures, worksheets, and observation sheet enclosed used to see keterlaksanaan RPP has been designed.

Implementation stage: at this stage the researchers who act as teachers carry out the scenario for the experimental and control class. First, before the treatment is given to control and experiment class were given a pretest. The purpose of giving this pre-test is to determine the ability of beginning students. And the continuation of the treatment in the experimental class using the practical approach to the environment, while the control class just use the lecture method. Furthermore, given the matter of post-test as a form of evaluation and administration of students' learning motivation with questionnaire to control and experiment class.

Phase analysis: at this stage the researchers conducted an analysis of data have been obtained in the form of a questionnaire learning motivation and achievement test. Then proceed with the preparation of research reports.

\section{RESULTS AND DISCUSSION}

Research result

Motivation Questionnaire Results of Classroom and Experiment Control

The initial step in processing motivation questionnaire is to calculate the number of students who choose to strongly agree (SS), agree (S), disagree (TS) and strongly disagree (STS) on every item. Only then can be calculated percentage of agree / disapproval for each item. Based on the results of these percentages can be determined interpretation. The results of the control class motivation questionnaire are presented in Table 1.

Based on Table 1 it can be seen that the outline of each indicator on the control class has been reached. This can be seen from the percentages and positive statements and negative interpretation of each 
indicator $>60 \%$ except indicators 1 positive statements and indicators 2 negative statement was $<60 \%$. While the experimental class, as well as the percentage of positive and negative statements interpretation of each indicator that is $>60 \%$. So if compared to the results of the experimental class on motivation questionnaire is greater than the control class.

TABLE I

RESULTS OF LEARNING MOTIVATION QUESTIONNAIRE OF CONTROL AND EXPERIMENT CLASSROOM

\begin{tabular}{|c|c|c|c|c|}
\hline \multirow[t]{2}{*}{ No } & \multirow[t]{2}{*}{ Indicator } & \multirow[t]{2}{*}{ Statement } & Control class & $\begin{array}{l}\text { Experiment } \\
\text { class }\end{array}$ \\
\hline & & & $\begin{array}{c}\text { Percentage } \\
\text { Interpretation }\end{array}$ & $\begin{array}{c}\text { Percentage } \\
\text { Interpretation }\end{array}$ \\
\hline \multirow[t]{2}{*}{1} & \multirow{2}{*}{$\begin{array}{l}\text { The drive to } \\
\text { learn } \\
\text { chemistry }\end{array}$} & Positive & $42,39 \%$ & $74,17 \%$ \\
\hline & & Negative & $\begin{array}{l}64,13 \% \\
\text { Strong }\end{array}$ & $\begin{array}{l}77,50 \% \\
\text { Strong }\end{array}$ \\
\hline \multirow[t]{2}{*}{2} & \multirow{2}{*}{$\begin{array}{l}\text { Their desire } \\
\text { to obtain } \\
\text { good } \\
\text { learning } \\
\text { results }\end{array}$} & Positive & $\begin{array}{l}72,82 \% \\
\text { Strong }\end{array}$ & $\begin{array}{c}85 \% \\
\text { Very strong }\end{array}$ \\
\hline & & Negative & $\begin{array}{l}58,69 \% \\
\text { Enough }\end{array}$ & $\begin{array}{l}90 \% \\
\text { Very strong }\end{array}$ \\
\hline \multirow[t]{2}{*}{3} & \multirow[t]{2}{*}{$\begin{array}{l}\text { Hopes of } \\
\text { ideals }\end{array}$} & Positive & $\begin{array}{l}64,13 \% \\
\text { Strong }\end{array}$ & $\begin{array}{l}77,50 \% \\
\text { Strong }\end{array}$ \\
\hline & & Negative & $\begin{array}{l}67,39 \% \\
\text { Strong }\end{array}$ & $\begin{array}{c}82,50 \% \text { Very } \\
\text { strong }\end{array}$ \\
\hline \multirow[t]{2}{*}{4} & \multirow{2}{*}{$\begin{array}{l}\text { Their } \\
\text { interest in } \\
\text { learning } \\
\text { activities }\end{array}$} & Positive & $\begin{array}{l}73,91 \% \\
\text { Strong }\end{array}$ & $\begin{array}{l}71,67 \% \\
\text { Strong }\end{array}$ \\
\hline & & Negative & $\begin{array}{l}71,73 \% \\
\text { Strong }\end{array}$ & $\begin{array}{l}65,83 \% \\
\text { Strong }\end{array}$ \\
\hline \multirow[t]{2}{*}{5} & \multirow{2}{*}{$\begin{array}{l}\text { Their need } \\
\text { for students } \\
\text { to gain an } \\
\text { appreciation } \\
\text { of learning }\end{array}$} & Positive & $\begin{array}{l}66,30 \% \\
\text { Strong }\end{array}$ & $\begin{array}{l}78,33 \% \\
\text { Strong }\end{array}$ \\
\hline & & Negative & $\begin{array}{l}73,91 \% \\
\text { Strong }\end{array}$ & $\begin{array}{l}71,67 \% \\
\text { Strong }\end{array}$ \\
\hline \multirow[t]{2}{*}{6} & \multirow{2}{*}{$\begin{array}{l}\text { Their } \\
\text { classroom } \\
\text { environment } \\
\text { conducive }\end{array}$} & Positive & $\begin{array}{c}75 \% \\
\text { Strong }\end{array}$ & $\begin{array}{c}81,67 \% \text { Very } \\
\text { strong }\end{array}$ \\
\hline & & Negative & $\begin{array}{l}73,91 \% \\
\text { Strong }\end{array}$ & $\begin{array}{c}85 \% \\
\text { Very strong }\end{array}$ \\
\hline
\end{tabular}

Based on statistical calculation normality test showed that the data on the control and experimental classes are normally distributed. Therefore, to determine whether there are differences in the two performed by t-test and obtained the value 0.524 . Motivation to learn the difference between control and experimental classes are presented in Table 2.

TABLE 2

RESULTS DIFFERENCES IN LEARNING MOTIVATION QUESTIONNAIRE OF CONTROL AND EXPERIMENT CLASSROOM

\begin{tabular}{llcc}
\hline No & $\begin{array}{c}\text { Value } \\
\text { Mean } \pm \text { sd }\end{array}$ & Control class & Experiment Class \\
& $41,48 \pm 5,57$ & $47,87 \pm 5,85$ \\
\hline 1 & Highest score & 55 & 64 \\
\hline 2 & Lowest score & 28 & 39 \\
\hline
\end{tabular}

Effect of Environmental Approach to Student Motivation
Having in mind of the motivation questionnaire normality test results of each class, it can look for the influence of environmental approaches on the students motivation to use the formula effect size and obtained values of 1.15 (in the table 0.3749), so that percentage to $37.49 \%$. Based on the calculation effect size of student motivation can be concluded that the influence of environmental approach to the learning outcomes of students belonging to the high criteria for effect size is ES> 1.

\section{Learning Outcomes Grade Control and Experiment}

In the control group there were 23 students and 30 students in experimental class who follow the learning process. Based on the statistical test for normality result classroom learning control and experiment presented in Table 3.

\begin{tabular}{|c|c|c|c|}
\hline No & $\begin{array}{c}\text { Value } \\
\text { Mean } \pm \text { sd }\end{array}$ & Control class & Experiment class \\
\hline 1 & Pretest & $46,30 \pm 21,38$ & $65,10 \pm 36,20$ \\
\hline 2 & Posttest & $55,93 \pm 15,51$ & $65,12 \pm 29,64$ \\
\hline
\end{tabular}

\section{Differences Learning Outcomes Grade Control and} Experimen

On normality test results of pretest control and experiment class shows that one among distributed data is not normal. So to test his hypothesis used UMann-Whitney test and obtained Asym. Sig. values (2-tailed) is 0.187 , which means there is no difference between the initial ability of control and experimental classes. Therefore, to determine differences in learning outcomes between control and experimental classes use the value of the posttest. In the post-test normality test showed that one among the data were not normally distributed. So to test his hypothesis used U Mann-Whitney test and obtained Asymp. Sig. values (2-tailed) 0.026, which means there are differences in learning outcomes between the control and experimental classes.

\section{Effect of Environmental Learning Approach to Student Results}

Having in mind the learning outcomes of each class, are used to determine the influence of the learning environment on student learning outcomes using effect size. Based on the calculation of the effect size obtained values of 0.63 (in the table 
0.2357 ) so the percentage is $23.57 \%$. Effect size of the calculation result of learning can be concluded that the influence of environmental approach to the learning outcomes for students classified as moderate effect size is $>0.4$.

\section{Discussion}

\section{Classroom Learning Process Control}

During the learning process there are some students who do not listen to the teacher's explanations, there is a busy themselves (talking with friends ) and there is also another lesson task. Even some students out of the classroom with a reason to washroom. As teachers deliver subject only a few people are paying attention. When the teacher gives students the chance to ask questions about the subject that was submitted, no student is going to ask. Then the teacher went on to explain the hope that they have understood the subject described earlier.

During the learning process seen student lackluster in completing the tasks assigned by the teacher and less enthusiastic when the teacher explains the subject. Learning is done on the control class is the teacher using the lecture method in presenting the subject. This lecture method causes students to feel bored and less motivated to participate in the learning process. This is in accordance with the submitted [7] that the dominance of conventional learning process such as the use of lecture and administration tasks performed by teachers will result in a lack of motivation to learn and low student learning outcomes.

\section{Experiment Classroom Learning Process}

During the learning process of students seemed enthusiastic to follow. Students listen to the directives given by the teacher and the learning environment is fairly quiet. Several students asked by show of hands later after a welcome by teachers and then they asked. As teachers share worksheets and ask the students to work on the problems that student worksheet, they do it by discussing with the group. This is in line with the views expressed by Moh Uzer Usman (2002) that teaching by empowering small group allows students to learn more actively, giving a sense of responsibility is greater, the development of creativity and leadership qualities in students, and can meet the needs of students optimally.

During do in the laboratory and do the problems on worksheets, if one is not understood them directly to ask the teacher by show of hands first. This makes the learning environment more conducive for interaction well between teachers and students. The learning process such as this provides an opportunity for students to dare to express their opinions and answer his questions in accordance with his knowledge. Thus the students' answers are not completely the same as the book, but the result of knowledge developed in accordance with the results of the experiment.

\section{Student Motivation}

Having in mind the motivation questionnaire normality test results of each class, it can be searched effecct size motivation to learn in the control and experimental classroom. Based on the calculation effect size learning motivation of control and experimental classroom values obtained of 1.15 (in the table 0.3749 ), so that percentage to $37.49 \%$.

Value of effect size is relatively high because of the value of the effect size range $0.4<\mathrm{ES}<1$. The difference in the motivation to learn this as the effect of the use of environmental approach in the learning process in the experimental class. This is in accordance with the opinion of [5] which states that the use of environmental approach in the learning process will encourage learning fun and to improve students' motivation. Thus it would make students more stepped up its efforts to obtain satisfactory academic results.

Through environmental approach students may be more motivated to follow the learning process. The high motivation in this study will have an impact on learning outcomes. Atmosphere or environment conducive to learning in the classroom that will affect the students' motivation in school. According to [6] motivation to learn it well can be developed, improved or modified through learning and training through environmental influences. That is, a good learning environment tends to encourage children to learn in a quiet, comfortable and concentration. [6] also stated that with the 
motivation to encourage and provide encouragement for someone to achieve success. Motivation will encourage and guide one's actions so as to direct the activities that correspond with the objectives to be achieved. Strong motivation can make a student able to work more extra to achieve the learning outcomes as desired.

\section{Student learning outcomes}

On the pretest of normality test results obtained control and experimental classes that are not normally distributed data. Therefore, to test the hypothesis used non-parametric statistical tests that U mann-Whitney and Asym values obtained. Sig. (2- tailed) is 0.187 . This means that Ho rejected and Ha received or there is no difference between the initial ability of control and experimental classes. So as to determine differences in learning outcomes between control and experimental classes use the value of the post-test.

In the post-test of normality test showed that one among the data were not normally distributed. So to test of his hypothesis used non-parametric statistical tests Umann-Whitney and Asymp values obtained. Sig. (2-tailed) is 0.026, which means Ha accepted and Ho is rejected or there is a difference in student learning outcomes between control and experimental classes.

Learning with environmental approach involving students directly. This approach assumes that the learning activities will attract the attention of students when it learned removed from the environment, so that what is learned in touch with the life and environmental benefits. This is in accordance with the views expressed by Yulianto (2002) that the environmental approach means linking environment in a learning process in which the environment is used as a learning resource. Learning resources are intended practicum subject are easily available and tightly close to the daily lives of students. This is supported also by the opinion [7] which states

that the best learning is through direct experience. This means that in learning through direct experience students are not merely observe directly, but he should live, directly involved in the actions and responsible for the results.
Differences in learning outcomes between the control and experimental classes can be determined using the formula effect size. Based on the results of the calculation of effect size class learning control and experimental values obtained of 0.63 (in the table 0.2357 ) so the percentage is $23.57 \%$. This means that the effect size in the criteria for being classified as the value of the effect size have range $0.4<\mathrm{ES}<1$. Learning in the control classes that only use the lecture method tends to make students feel bored and less motivated to participate in the learning process, while in the classroom learning experiment using environmental approach tends to be more fun because the students can be involved directly in the learning process.

Learning to approach the environmental impact is not too large to student learning outcomes. This is because there are other factors that affect student learning outcomes among students of physiologic factors. Physiological factors affecting students is the time spent in the learning process. The learning process in the classroom experiment took place during the day is at 9:15 to $11: 25 \mathrm{pm}$ and the provision of post-test question at 11:25 to $11: 45 \mathrm{pm}$. While in class learning control at 08:30 to $09: 40 \mathrm{pm}$ and the provision of post-test after the first break, or approximately at 9:40 to 10:00 pm.

According to [8] that the physiological factors that can affect student learning, among others fatigue in learning. This fatigue can be distinguished between mental fatigue and physical fatigue. People who experience physical fatigue in the body there is a substance that poisoned. Meanwhile, people who experience mental fatigue can be viewed their lethargy and boredom that will lose interest and the urge to produce something.

\section{IV.CONCLUSIONS AND SUGGESTIONS}

Based on data analysis that has been done, it can be concluded that there are differences in students' motivation in class XI IPA at SMAN 1 Sungai Raya is taught using the approach of the environment and is taught by lecture method on the acid-base subject. In addition, there are differences in learning outcomes of students between classes taught using the approach of the environment and is taught by lecture method on the acid-base subject. Further study using environmental approach gives effect to the motivation and learning outcomes of students with the calculation of effect 
size of 1.15 and a percentage of $37.49 \%$ for the motivation and 0.63 and a percentage of $23.57 \%$ for learning outcomes.

\section{Suggestion}

From the research that has been done, there are some findings that can serve as suggestions in order to develop chemistry in high school. As for suggestions in this research study by using environmental approach can improve motivation and student learning outcomes, it is expected to teachers and prospective teachers can develop it as an alternative to school learning, especially in subject of acidbase and preferably before doing practical teacher demonstrates first so that students better understand before making his own lab.

\section{ACKNOWLEDGMENT}

The author would like to thank friends, colleagues and associates who have helped this research

\section{REFERENCES}

[1] Slameto, Belajar dan Faktor-faktor yang Mempengaruhinya, Jakarta: PT Rineka Cipta. 2003.

[2] Syukri, Kimia Dasar 1, Bandung: ITB. 1999.

[3] Departemen Pendidikan silabus Nasional, Pedoman khusus pengembangan dan penilaian kurikulum 2004, Jakarta: Direktorat Pendidikan Menengah Umum. 2003.

[4] Khusnin, Pembelajaran dengan Pendekatan Lingkungan, https://khusnin. wordpress. com/2008 /09 /03/ pembelajaran-pendekatan-lingkungan. Html, 2008.

[5] Sastrawijaya, Perencanaan Lingkungan . Jakarta: Rinika Cipta, 2000.

[6] Hamzah B. Uno, Teori Motivasi dan Pengukurannya Analisis Di Bidang Pendidikan, Jakarta:Bumi Aksara. 2013.

[7] Arsyad, Azhar, Media Pengajaran, Jakarta: Raja Grafindo Persada, 2000.

[8] Winarno Surachmad, Pengantar Penelitian Ilmiah, Dasar Metode dan Teknik, Bandung: Tarsito, 1984

[9] Trianto, Mendesain Model Pembelajaran InovatifProgresif, Jakarta: Prenada Group, 2010. 